\title{
Symplocosionosides A-C, Three Megastigmane Glycosides, a Neolignan Glucoside, and Symplocosins A and B, Two Triterpene Glycosyl Esters from the Leaves of Symplocos cochinchinensis var. Philippinensis
}

\author{
Wen-Hu Cai ${ }^{1}$, Katsuyoshi Matsunami ${ }^{1}$, Hideaki Otsuka ${ }^{1}$, Yoshio Takeda ${ }^{2}$ \\ ${ }^{1}$ Graduate School of Biomedical Sciences, Hiroshima University, Hiroshima, Japan; ${ }^{2}$ Faculty of Pharmacy, Yasuda Women's Uni- \\ versity, Hiroshima, Japan. \\ Email: hotsuka@hiroshima-u.ac.jp
}

Received July $8^{\text {th }}, 2011$; revised August 31 ${ }^{\text {st }}, 2011$; accepted September $9^{\text {th }}, 2011$.

\begin{abstract}
From the 1-BuOH-soluble fraction of a MeOH extract of the leaves of Symplocos cochinchinensis var. philippinensis, 12 compounds were isolated. Spectroscopic analyses of compounds 1 - 3 established their structures to be megastigmane glycosides, named symplocosionosides A-C. The absolute structure of 1 was determined by the modified Mosher's method. Compound 4 was found to be a neolignan glucoside and named symplocosneolignan. The structures of compounds 5 and 6, named symplocosins $A$ and B, were elucidated to be the saponins of hederagenin sugar esters. The structures of the remaining known compounds $(7$ - 12) were identified by comparison of spectroscopic data with those reported in the literature.
\end{abstract}

Keywords: Symplocos Cochinchinensis var. Philippinensis, Symplocaceae, Megastigmane Glycoside, Neolignan Glucoside, Triterpene Glycosyl Ester, Modified Mosher's Method

\section{Introduction}

Genus Symplocos comprises about 300 species, which are mainly found in tropical, except for Africa, and subtropical areas, with a small number of species in the temperate zone. Symplocos cochinchinensis (Loureiro) Spencer Le Marchant Moore var. philippinensis (Brand) Nootboom (Symplocaceae) is an evergreen tall tree, which is distributed in the Amami and Okinawa Islands, Taiwan, Southern China and Indochina. It grows up to about $15 \mathrm{~m}$ in height and bears white flowers in spikes [1]. So far as we know, no chemical investigation has been performed on this plant. Even for its elementary species, S. cochinchinensis (Loureiro) Spencer Le Marchant Moore, only few pharmacological works have been performed on its extract [2-4]. Thus, we were promted to invetigate the chemical constituents in the title plant. From the 1-BuOH-soluble fraction of a $\mathrm{MeOH}$ extract of the leaves of $S$. cochinchinensis var. philippinensis, three new megastigmane glycosides, named symplocosiono- sides A-C (1-3), a new neolignan glucoside, named symplocosneolignan A (4), and two new triterpene glycosyl esters, named symplocosins A and B $(5,6)$, together with six known compounds, dendranthemoside A (7) [5], 4,5dihydroblumenol (8) [6], alangionoside B (9) [7], ampelopsisionoside (10) [8], citroside A (11) [9], and nigaichigoside F1 (12) [10] were isolated. This paper deals with structural elucidation of the new compounds.

\section{Results and Discussion}

From the 1-BuOH-soluble fraction of a $\mathrm{MeOH}$ extract of the leaves of $S$. cochinchinensis var. philippinensis, six new compounds (1-6) and six known (7-12) compounds were isolated by means of a combination of various chromatographic technique.

Symplocosionoside A (1), $[\alpha]_{\mathrm{D}}^{25}-44.0$, was isolated as an amorphous powder and its elemental composition was determined to be $\mathrm{C}_{24} \mathrm{H}_{42} \mathrm{O}_{11}$ by high-resolution (HR)electrospray ionization (ESI)-mass spectrometry (MS). 
Strong absorption bands at $3394 \mathrm{~cm}^{-1}$ and $1055 \mathrm{~cm}^{-1}$ in the IR spectrum indicated that symplocosionoside A (1) was a glycoside and in the NMR spectra, two anomeric carbon and proton signals $\left(\delta_{\mathrm{C}} 102.9\right.$ with $\delta_{\mathrm{H}} 4.33$ and $\delta_{\mathrm{C}} 110.9$ with $\left.\delta_{\mathrm{H}} 5.00\right)$ were observed. The ${ }^{1} \mathrm{H}-\mathrm{NMR}$ spectrum exhibited signals for two singlet and two doublet methyls, and one trans double bond. Of the 24 carbon NMR signals, 11 were assigned to those for a $\beta$-D-(6- $O-\beta$-Dapiofuranosyl) glucopyranoside moiety (Table 1) [11]. The absolute configurations of apiose and glucose were determined to be of the D-series by HPLC analysis of a hydrolyzate of 1 . The remaining 13 signals comprised of those of four methyls, two methylenes, two oxymethines, two methines, one quaternary carbon and a double bond. From the above evidence, the aglycone of symplocosionoside A (1) was assumed to have a megastigmane skeleton, and the proton spin-spin coupling sequence from $\mathrm{H}_{2}-2$ through $\mathrm{H}_{3}-10$ was revealed by the ${ }^{1} \mathrm{H}-{ }^{1} \mathrm{H}$ correlation spectroscopy (COSY) spectrum. Further detailed inspection of two-dimensional NMR spectra established

Table 1. ${ }^{13} \mathrm{C}-\mathrm{NMR}$ Data for Symplocosionoside A-C (1-3) and $1 \mathrm{a}\left(100 \mathrm{MHz}, \mathrm{CD}_{3} \mathrm{OD}\right)$.

\begin{tabular}{ccccc}
\hline $\mathbf{c}$ & $\mathbf{1}$ & $\mathbf{1 a}$ & $\mathbf{2}$ & $\mathbf{3}$ \\
\hline 1 & 35.8 & 35.9 & 44 & $37.0(36.4)^{b)}$ \\
2 & 48.0 & $51.3(-3.3)^{a)}$ & 52.5 & $48.8(50.3)$ \\
3 & 76.0 & $67.4(+8.6)$ & 215.0 & $63.8(62.5)$ \\
4 & 43.9 & $45.6(-1.7)$ & 46.2 & $48.0(47.4)$ \\
5 & 32.2 & 32.2 & 37.9 & $78.8(78.3)$ \\
6 & 58.6 & 58.6 & 78.2 & $119.0(118.6)$ \\
7 & 131.2 & 131.2 & 134.7 & $200.9(197.6)$ \\
8 & 138.4 & 138.5 & 134.3 & $101.4(100.9)$ \\
9 & 69.3 & 69.3 & 78.1 & $213.1(211.6)$ \\
10 & 24.0 & 24.0 & 21.5 & $26.7(26.6)$ \\
11 & 21.7 & 21.69 & 25.1 & $30.1(29.8)$ \\
12 & 31.9 & 31.9 & 25.4 & $32.5(32.3)$ \\
13 & 21.7 & 21.72 & 16.5 & $26.7(26.6)$ \\
$1^{\prime}$ & 102.9 & & 102.7 & $98.7(98.5)$ \\
$2^{\prime}$ & 75.0 & & 75.4 & $75.3(75.1)$ \\
$3^{\prime}$ & 78.0 & & 78.0 & $78.4(79.1)$ \\
$4^{\prime}$ & 71.8 & & 71.7 & $71.7(71.8)$ \\
$5^{\prime}$ & 76.7 & & 77.0 & $76.5(76.6)$ \\
$6^{\prime}$ & 68.6 & & 68.6 & $69.2(68.8)$ \\
$1^{\prime \prime}$ & 110.9 & & 110.0 & $105.0(105.1)$ \\
$2^{\prime \prime}$ & 78.0 & & 77.6 & $72.3(72.2)$ \\
$3^{\prime \prime}$ & 80.5 & & 80.5 & $74.1(74.2)$ \\
$4^{\prime \prime}$ & 75.1 & & 75.0 & $69.9(69.8)$ \\
$5^{\prime \prime}$ & 65.8 & & 65.7 & $66.3(66.1)$ \\
\hline
\end{tabular}

a) $\Delta \delta_{\text {1-1a. }}$ ) Data for $\mathrm{C}_{5} \mathrm{D}_{5} \mathrm{~N}$ solution. the structure of the aglycone moiety. Since the H-3 proton $\left(\delta_{\mathrm{H}} 3.83\right)$ was coupled with the axial protons at $\mathrm{H}-2$ and $\mathrm{H}-4$ with a coupling constant of $12 \mathrm{~Hz}$, the hydroxy substituent at the 3-position was placed in the equatorial position, and the similar coupling constants for H-4ax and H-5, and H-5 and H-6 also are favorable for placement of both of the methyl group at the 5-position and the side chain at the 6-position in the equatorial position. The site of sugar attachment was established to be to the hydroxy group at the 3-position by the HMBC correlation cross peak between $\mathrm{H}-1^{\prime}\left(\delta_{\mathrm{H}} 4.33\right)$ and C-3 $\left(\delta_{\mathrm{C}} 76.0\right)$. The absolute configuration at the 3-position was first expected to be $S$ from the empirical $\beta$-D-glucopyranosylation-induced shift-trend rule for glycoside (1) and the aglycone (1a) (Table 1) [12], and then the final confirmation of that of the aglycone (1a) was achieved by the modified Mosher's method (Figure 2) [13]. Therefore, the structure of symplocosionoside A (1) was elucidated to be $(3 S, 5 R, 6 R, 7 E, 9 R)$-megastigman-7-ene-3, 9-diol $3-O-\beta$-D-(6'- $O-\beta$-D-apiofuranosyl) glucopyranoside, as shown in Figure 1.

Symplocosionoside B (2), $[\alpha]_{D}^{26}-63.0$, was isolated as an amorphous powder and its elemental composition was determined to be $\mathrm{C}_{24} \mathrm{H}_{40} \mathrm{O}_{12}$ by HR-ESI-MS. The IR

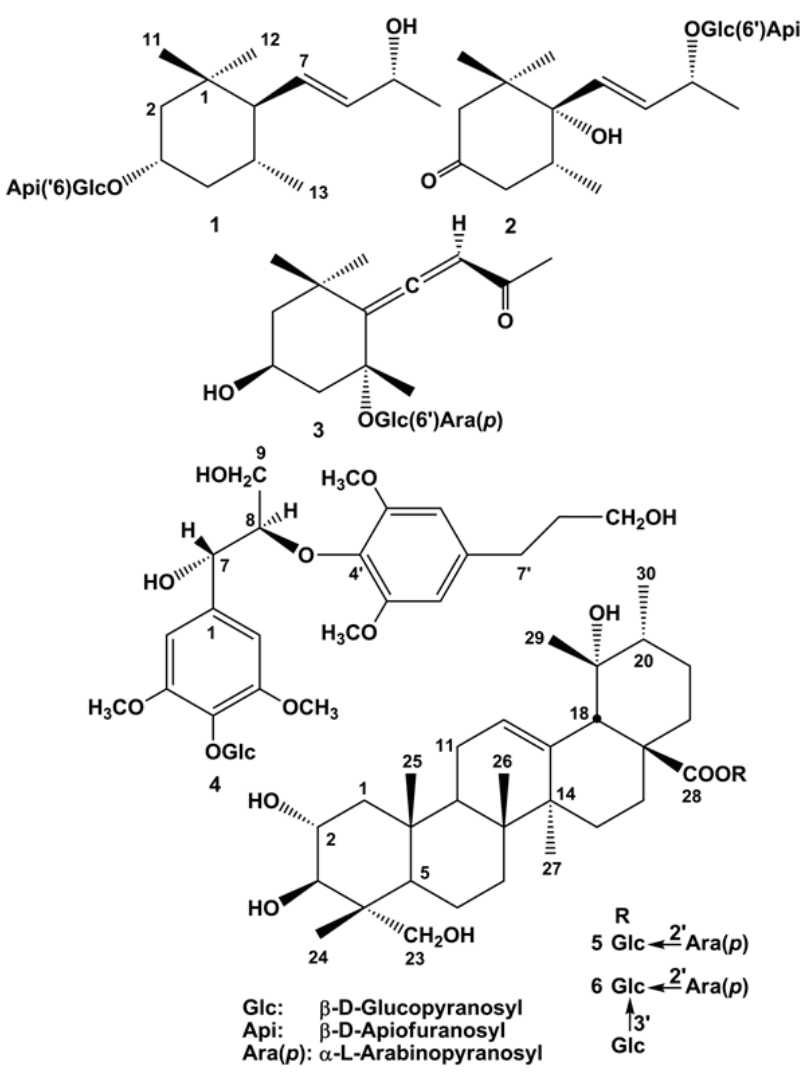

Figure 1. Structures of isolated new compounds. 


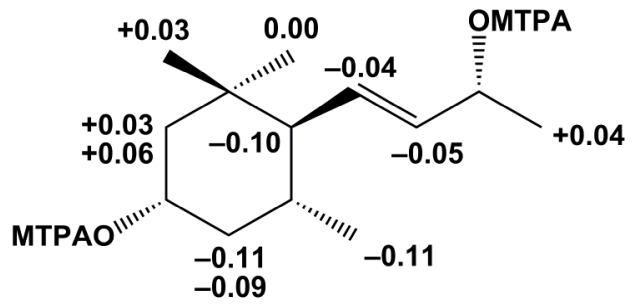

Figure 2. Results of modified Mosher's method for symplocosionoside A (1).

spectrum exhibited a glycosidic feature $\left(3399 \mathrm{~cm}^{-1}\right.$ and $1056 \mathrm{~cm}^{-1}$ ) and the presence of a ketonic functional group $\left(1694 \mathrm{~cm}^{-1}\right)$. In the ${ }^{1} \mathrm{H}-\mathrm{NMR}$ spectrum, the signals for two singlet methyls, two doublet methyls, one trans double bond and two anomeric protons were observed. The ${ }^{13} \mathrm{C}$-NMR spectrum exhibited 24 signals, 11 of which were assignable to those of a $9-O-\beta-\mathrm{D}-(6-O-$ $\beta$-D-apiofur-anosyl) glucopyranoside moiety. The absolute configurations of apiose and glucose were determined to be of the D-series by HPLC analysis of the hydrolyzate of 2 . The remaining 13 signals comprised those of four methyls, two methylenes, one oxymethine, one methine, one double bond, two quaternary carbons and a ketone functional group. From the above evidence together with the information obtained from two dimensional spectra, the structure of symplocosonoside B (2) was determined to be 3-keto-6-hydro- xymegastigmane glycoside, as shown in Figure 1. From the proton-proton coupling constant, $J_{4 a x-5}=14 \mathrm{~Hz}$, the methyl group at the 5 -position was placed in an equatorial position, and then the correlation cross peak between $\mathrm{H}-5\left(\delta_{\mathrm{H}} 2.28\right)$ and H-7 $\left(\delta_{\mathrm{H}}\right.$ 5.74) observed on phase-sensitive (PS)-nuclear Overhauser effect spectroscopy (NOESY) allowed placement of the side chain also in an equatorial position. Based on the octant rule, the absolute configuration at the 5-position was determined to be $R$ from the positive Cotton effect at $289 \mathrm{~nm}$ in the CD spectrum and thus the 6-position must have the $S$ configuration. By comparing the reported data, the absolute configuration at the 9-position was determined to be $R$, and the linkage of the sugar unit to the hydroxy group at the 9-positon was confirmed by the HMBC correlation cross peak between $\mathrm{H}-1^{\prime}\left(\delta_{\mathrm{H}} 4.34\right)$ and C-9 $\left(\delta_{\mathrm{C}} 78.1\right)$. Therefore, the structure of symplocosionoside B (2) was elucidated to be $(5 R, 6 S$, $7 E, 9 R)$-megastigman-7-en-9-ol-3-one $9-O-\beta$-D-(6'-O- $\beta$ D-apiofuranosyl) glucopyranoside.

Symplocosonoside C (3), $[\alpha]_{D}^{25}-57.9$, was isolated as an amorphous powder and its elemental composition was determined to be $\mathrm{C}_{24} \mathrm{H}_{38} \mathrm{O}_{12}$ by HR-ESI-MS. The IR spectrum exhibited a characteristic absorption band for an allenic part $\left(1938 \mathrm{~cm}^{-1}\right)$, and the presence of this func- tional group was supported by the ${ }^{13} \mathrm{C}$-NMR spectrum $\left(\delta_{\mathrm{C}} 118.6,197.6\right.$ and 100.9 in $\left.\mathrm{C}_{5} \mathrm{D}_{5} \mathrm{~N}\right)$. Other ${ }^{13} \mathrm{C}-\mathrm{NMR}$ signals showed good similarity to those of citrosides A and B, isolated from Citrus unshiu [9], except for the presence of signals for a terminal $\alpha$-arabinopyranose, and the upfield and downfield shifts of the C-5' $\left(\delta_{\mathrm{C}} 76.6\right.$ in $\left.\mathrm{C}_{5} \mathrm{D}_{5} \mathrm{~N}\right)$ and $\mathrm{C}-66^{\prime}\left(\delta_{\mathrm{C}} 68.8\right.$ in $\left.\mathrm{C}_{5} \mathrm{D}_{5} \mathrm{~N}\right)$ signals. A significant cross peak, observed between $\mathrm{H}-1 "{ }^{\prime \prime}\left(\delta_{\mathrm{H}} 5.05\right.$ in $\left.\mathrm{C}_{5} \mathrm{D}_{5} \mathrm{~N}\right)$ and $\mathrm{C}-6^{\prime}$ in the HMBC spectrum, confirmed the sugar linkage. The absolute configurations of arabinose and glucose were determined to be of the L- and D-series, respectively, by HPLC analysis of the hydrolyzate of 3 using the chiral detector. The axis chirality of the allene part was determined to be the same as that of citroside A, tentatively $R$, as judged on comparison of the ${ }^{13} \mathrm{C}$-NMR chemical shift of C-7 $\left(\delta_{\mathrm{C}} 197.6\right.$ in $\left.\mathrm{C}_{5} \mathrm{D}_{5} \mathrm{~N}\right)$ with those for citrosides A (C-7: $\delta_{\mathrm{C}}$ 197.6) and B (C-7: $\delta_{\mathrm{C}}$ 199.0). Therefore, the structure of symplocosionoside $\mathrm{C}$ (3) was elucidated to be citroside A 6 '- $O-\alpha$-L-arabinopyranoside, as shown in Figure 1.

Symplocosneolignan (4), $[\alpha]_{\mathrm{D}}^{25}-13.5$, was isolated as an amorphous powder and its elemental composition was determined to be $\mathrm{C}_{28} \mathrm{H}_{40} \mathrm{O}_{14}$ by HR-ESI-MS. The IR spectrum showed that symplocosneolignan (4) was a glycosidic compound $\left(3395 \mathrm{~cm}^{-1}\right)$ with aromatic ring (s) $\left(1592 \mathrm{~cm}^{-1}\right)$. A UV absorption band $(269 \mathrm{~nm})$ also supported the presence of the aromatic ring (s). In the ${ }^{1} \mathrm{H}$ NMR spectrum, signals for two singlet aromatic protons $\left(\delta_{\mathrm{H}} 6.53\right.$ and 6.75$)$, two methoxy protons $\left(\delta_{\mathrm{H}} 3.79\right.$ and $3.84)$, and an anomeric proton $\left(\delta_{\mathrm{H}} 4.83\right)$ were observed (Table 2). Each of the aromatic signals accounted for two protons and that of the methoxy signals six protons. The ${ }^{13} \mathrm{C}$-NMR spectrum exhibited 22 signals, of which six were assignable to $\beta$-glucopyranose. As to the remaining 16 signals, two methoxy signals were expected to include those of four carbons from their peak heights and each of the four aromatic signals was obviously for two carbons. Thus, the two aromatic rings must be substituted symmetrically and the other signals comprised those of two primary alcohols, two methylenes and two oxymethines. The proton chains from $\mathrm{H}-7$ to $\mathrm{H}-9$ and $\mathrm{H}-$ $7^{\prime}$ to $\mathrm{H}-9$ ' were assigned by inspection of the ${ }^{1} \mathrm{H}-{ }^{1} \mathrm{H}$ COSY spectrum, and the correlation cross peaks between $\mathrm{H}-8\left(\delta_{\mathrm{H}} 4.18\right)$, and $\mathrm{C}-1\left(\delta_{\mathrm{C}} 139.5\right)$ and $\mathrm{C}-4{ }^{\prime}\left(\delta_{\mathrm{C}} 134.9\right)$ in the HMBC spectrum established the structure of symplocosneolignan (4), as shown in Figure 1. Other HMBC correlations shown in Figure 3 also supported the structure. The site of the sugar linkage was determined to be to the hydroxy group at the 4-position, judging from the cross peak between $\mathrm{H}-1^{\prime}$ and $\mathrm{C}-4\left(\delta_{\mathrm{C}} 135.6\right)$ in the HMBC spectrum, and the mode of linkage to be $\beta$ from the coupling constant $(J=8 \mathrm{~Hz})$ of the anomeric proton. 
Table 2. NMR spectral data for symplocosneolignan 4 and 4a $\left[\mathrm{CD}_{3} \mathrm{OD}, 100 \mathrm{MHz}\left({ }^{13} \mathrm{C}\right)\right.$ and $\left.400 \mathrm{MHz}\left({ }^{1} \mathrm{H}\right)\right]$.

\begin{tabular}{|c|c|c|c|c|}
\hline & \multicolumn{2}{|r|}{4} & \multicolumn{2}{|r|}{$4 a$} \\
\hline & $\mathrm{C}$ & $\mathrm{H}$ & $\mathrm{C}$ & $\mathrm{H}$ \\
\hline 1 & 139.5 & & 132.4 & \\
\hline 2,6 & 106.1 & $6.75(2 \mathrm{H}, \mathrm{s})$ & 105.4 & $6.67(2 \mathrm{H}, \mathrm{s})$ \\
\hline 3,5 & 153.9 & & 149.1 & \\
\hline 4 & 135.6 & & 133.2 & \\
\hline 7 & 74.1 & $4.93(1 \mathrm{H}, \mathrm{d}, 5)$ & 74.3 & $4.91(1 \mathrm{H}, \mathrm{d}, 5)$ \\
\hline 8 & 87.2 & $4.18(1 \mathrm{H}, \mathrm{ddd}, 6,6,5)$ & 87.5 & $4.18(1 \mathrm{H}, \mathrm{ddd}, 5,5,5)$ \\
\hline \multirow[t]{2}{*}{9} & 61.5 & $3.86(1 \mathrm{H}, \mathrm{dd}, 12,6)$ & 61.7 & $3.88(1 \mathrm{H}, \mathrm{dd}, 12,5)$ \\
\hline & & $3.56(1 \mathrm{H}, \mathrm{dd}, 12,6)$ & & $3.55(1 \mathrm{H}, \mathrm{dd}, 12,5)$ \\
\hline$-\mathrm{OCH}_{3}$ & 57.0 & $3.79(6 \mathrm{H}, \mathrm{s})$ & 56.9 & $3.80(6 \mathrm{H}, \mathrm{s})$ \\
\hline $1^{\prime}$ & 140.0 & & 140.0 & \\
\hline $2^{\prime}, 6^{\prime}$ & 107.0 & $6.53(2 \mathrm{H}, \mathrm{s})$ & 107.1 & $6.54(2 \mathrm{H}, \mathrm{s})$ \\
\hline $3^{\prime}, 5^{\prime}$ & 154.4 & & 154.4 & \\
\hline $4^{\prime}$ & 134.9 & & 135.0 & \\
\hline $7^{\prime}$ & 33.4 & $2.64(2 \mathrm{H}, \mathrm{t}, 7)$ & 33.5 & $2.63(2 \mathrm{H}, \mathrm{t}, 7)$ \\
\hline $8^{\prime}$ & 35.4 & $1.83(2 \mathrm{H}, \mathrm{tt}, 7,7)$ & 35.5 & $1.83(2 \mathrm{H}, \mathrm{tt}, 7,7)$ \\
\hline $9^{\prime}$ & 62.3 & $3.59(2 \mathrm{H}, \mathrm{t}, 7)$ & 62.2 & $3.57(2 \mathrm{H}, \mathrm{t}, 7)$ \\
\hline$-\mathrm{OCH}_{3}$ & 56.7 & $3.84(6 \mathrm{H}, \mathrm{s})$ & 56.7 & $3.85(6 \mathrm{H}, \mathrm{s})$ \\
\hline $1 "$ & 105.6 & 4.83 (1H. d, 8) & & \\
\hline $2 "$ & 75.8 & $3.58(1 \mathrm{H}, \mathrm{m})$ & & \\
\hline $3 "$ & 77.9 & $3.43(1 \mathrm{H}, \mathrm{m})$ & & \\
\hline $4 "$ & 71.4 & $3.43(1 \mathrm{H}, \mathrm{m})$ & & \\
\hline $5^{\prime \prime}$ & 78.4 & $3.21(1 \mathrm{H}, \mathrm{m})$ & & \\
\hline \multirow[t]{2}{*}{$6 "$} & 62.7 & $3.77(1 \mathrm{H}, \mathrm{dd}, 12,2)$ & & \\
\hline & & $3.66(1 \mathrm{H}, \mathrm{dd}, 12,6)$ & & \\
\hline
\end{tabular}

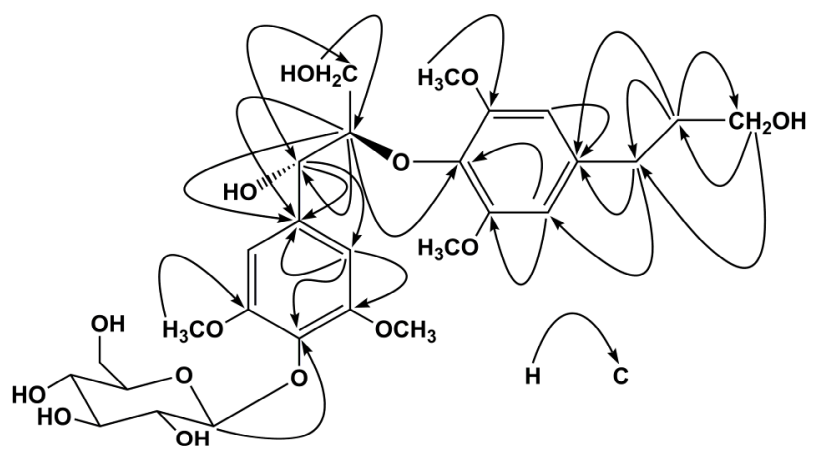

Figure 3. Diagnostic HMBC correlations for symplocosneolignan (4).

Judging from the coupling constant $(J=5 \mathrm{~Hz})$ for $\mathrm{H}-7$ and 8, symplocosneolignan (4) was concluded to possess the erythro relative stereochemistry [15]. Enzymatic hydrolysis of symplocosneolignan (4) gave its aglycone (4a), whose $J_{7-8}$ remained as $5 \mathrm{~Hz}$ [16]. Judging from the negative Cotton effect at $242 \mathrm{~nm}$, the absolute configuration of 4 was determined to be $7 S, 8 R$ [16-18]. Therefore, the structure of symplocosneolignan (4) was elucidated to be $(7 S, 8 R)-4,7,9,9^{\prime}$-tetrahydroxy-3,5,3',5'-tetramethoxy$8,4^{\prime}$-oxyneolignan $4-O-\beta$-D-glucopyranoside, as shown in Figure 1.

Symplocosin A (5), $[\alpha]_{\mathrm{D}}^{25}+14.8$, was isolated as an amorphous powder and its elemental composition was determined to be $\mathrm{C}_{41} \mathrm{H}_{66} \mathrm{O}_{15}$ by HR-ESI-MS. The IR spectrum showed that 5 was a glycosidic compound $\left(3382 \mathrm{~cm}^{-1}\right)$ and the ${ }^{13} \mathrm{C}$-NMR spectroscopic data were similar to those of niga-ichigoside F1 (13) (Table 3) [10], which co-occurred in this plant, except for the appearance of five signals assignable for $\alpha$-arabinopyranoside (Table 3). Arabinose and glucose were similarly determined by HPLC to be of the L- and D-series, respectively. The position of arabinose was determined to be the hydroxy group at the 2'-position from the HMBC correlation between $\mathrm{H}-1^{\prime \prime}\left(\delta_{\mathrm{H}} 5.14\right)$ and C-2' $\left(\delta_{\mathrm{C}} 80.9\right)$. Therefore, the structure of 5 was elucidated to be $2 \alpha, 3 \alpha$, $19 \alpha$, 23-tetrahydroxyurs-12-en-28-oic acid (= 19 $\alpha$-hydroxyasiatic acid) $\beta$-D-(2'- $O-\beta$-L-arabinopyranosyl) glucopyranosyl ester, namely niga-ichigoside $\mathrm{F}_{1} 2^{\prime}-O-\beta$-Larabinopyranoside, as shown in Figure 1.

Symplocosin B (6), $[\alpha]_{\mathrm{D}}^{25}+9.1$, was also isolated as an amorphous powder and its elemental composition was determined to be $\mathrm{C}_{47} \mathrm{H}_{76} \mathrm{O}_{20}$ by HR-ESI-MS. The NMR spectral data of 6 showed high similarity to those of 5 , and the presence of two terminal sugars, $\alpha$-arbinopyranose and $\beta$-glucopyranose (Table 3 ). The positions of the sugars were established from the HMBC cross peaks between $\mathrm{H}-1^{\prime}\left(\delta_{\mathrm{H}} 6.07\right)$ and $\mathrm{C}-28\left(\delta_{\mathrm{C}} 177.0\right), \mathrm{H}-1^{\prime \prime}\left(\delta_{\mathrm{H}}\right.$ 5.38) and $\mathrm{C}-2^{\prime}\left(\delta_{\mathrm{C}} 77.4\right)$, and H-1"' $\left(\delta_{\mathrm{H}} 5.28\right)$ and C-3' $\left(\delta_{\mathrm{C}}\right.$ 88.1). Therefore, the structure of symplocosin B (6) was elucidated to be $2 \alpha, 3 \beta, 19 \alpha, 23$-tetrahydroxyurs-12-en28 -oic acid $\beta$-D-(2'- $O-\alpha$-L-arabinopyranosyl, 3'- $O-\alpha$-Dglucopy-ranosyl) glucopyranosyl ester, as shown in Figure 1.

From the leaves of $S$. cochinchiensis var. philippinensis, three new megastigmane diglycosides, named symploco- sionosides A-C (1-3), neolignan glucoside (4) and sym- plocosins $\mathrm{A}$ and $\mathrm{B}$, two ursane-type triterpenoid glycosyl esters $(5,6)$ were isolated. Their structures were eluci- dated by the spectroscopic evidence. The absolute struc- ture of 1 was finally determined by the modified Mosher's method and that of 4 by the Cotton effect, observed in the CD spectrum. Three species of Symplocos were medicinally used as "lodhra" in Indian system of traditional medicine, Ayurveda. For treatment of diabetes mellitus in Ayuveda, Symplocos species were given along with the juice of cucumber [19]. It is of interest for further works to define the compounds responsible for this treatment. 
Table $3 .{ }^{13} \mathrm{C}-\mathrm{NMR}$ data for compounds 5,6 and $12\left(\mathrm{C}_{5} \mathrm{D}_{5} \mathrm{~N}\right.$ + one drop of $\mathrm{D}_{2} \mathrm{O}, 150 \mathrm{MHz}$ ).

\begin{tabular}{|c|c|c|c|c|}
\hline c & & & 6 & $12^{\mathrm{a})}$ \\
\hline 1 & 47.6 & $(48.0)^{b)}$ & 47.6 & 47.9 \\
\hline 2 & 68.7 & (69.0) & 68.7 & 68.8 \\
\hline 3 & 78.1 & (78.4) & 78.3 & 78.2 \\
\hline 4 & 43.4 & (43.6) & 43.3 & 43.5 \\
\hline 5 & 47.9 & $(48.2)$ & 48.0 & 48.5 \\
\hline 6 & 18.5 & (18.8) & 18.6 & 18.7 \\
\hline 7 & 32.9 & $(33.1)$ & 33.1 & 33.1 \\
\hline 8 & 40.5 & (40.7) & 40.5 & 40.6 \\
\hline 9 & 47.7 & (47.9) & 47.7 & 47.9 \\
\hline 10 & 38.2 & (38.4) & 38.2 & 38.3 \\
\hline 11 & 24.1 & (124.3) & 24.1 & 24.2 \\
\hline 12 & 128.1 & (128.3) & 128.0 & 128.3 \\
\hline 13 & 139.3 & (139.5) & 139.4 & 139.2 \\
\hline 14 & 42.0 & $(42.2)$ & 42.1 & 42.1 \\
\hline 15 & 28.9 & $(29.2)$ & 29.0 & 29.1 \\
\hline 16 & 25.9 & $(26.2)$ & 25.7 & $26.0^{c)}$ \\
\hline 17 & 48.6 & $(48.7)$ & 48.6 & 48.5 \\
\hline 18 & 54.3 & $(54.5)$ & 54.3 & 54.4 \\
\hline 19 & 72.5 & $(72.7)$ & 72.5 & 72.5 \\
\hline 20 & 41.9 & $(42.1)$ & 41.9 & 42.1 \\
\hline 21 & 26.6 & $(26.8)$ & 26.6 & $27.0^{c)}$ \\
\hline 22 & 37.3 & $(37.4)$ & 37.1 & 37.7 \\
\hline 23 & 66.4 & (66.9) & 66.6 & 66.6 \\
\hline 24 & 14.0 & (14.3) & 14.0 & 14.2 \\
\hline 25 & $17.2^{c)}$ & (17.4) & 17.3 & $17.5^{d)}$ \\
\hline 26 & $17.3^{c)}$ & (17.3) & 17.3 & $17.5^{d)}$ \\
\hline 27 & 24.3 & $(24.3)$ & 24.3 & 24.5 \\
\hline 28 & 177.1 & (177.1) & 177.2 & 176.8 \\
\hline 29 & 26.8 & $(27.1)$ & 26.9 & 27.0 \\
\hline 30 & 16.5 & (16.7) & 16.6 & $16.7^{d)}$ \\
\hline $1^{\prime}$ & 94.0 & $(94.2)$ & 93.5 & 95.7 \\
\hline $2^{\prime}$ & 80.9 & (81.4) & 77.4 & 73.9 \\
\hline $3^{\prime}$ & 77.9 & $(78.6)$ & 88.1 & $78.8^{e)}$ \\
\hline $4^{\prime}$ & 70.6 & $(71.1)$ & $69.5^{c)}$ & 71.2 \\
\hline $5^{\prime}$ & 78.7 & (78.9) & 78.3 & $79.9^{e)}$ \\
\hline $6^{\prime}$ & 62.0 & (62.4) & 62.1 & 62.3 \\
\hline 1" & 106.0 & (106.5) & 104.6 & \\
\hline $2^{\prime \prime}$ & 73.0 & $(73.5)$ & 72.8 & \\
\hline 3" & 74.0 & $(74.4)$ & 74.5 & \\
\hline 4" & 69.0 & (69.4) & $69.6^{c)}$ & \\
\hline 5" & 67.0 & (67.4) & 67.2 & \\
\hline 1"' & & & 104.3 & \\
\hline 2"' & & & 75.1 & \\
\hline 3"' & & & $78.3^{d)}$ & \\
\hline 4"' & & & 71.3 & \\
\hline $5^{\prime \prime \prime}$ & & & $78.2^{d)}$ & \\
\hline 6"' & & & 61.7 & \\
\hline
\end{tabular}

a) Data taken from ref. 10. Data for $\mathrm{C}_{5} \mathrm{D}_{5} \mathrm{~N}$ without $\mathrm{D}_{2} \mathrm{O}$ at $25 \mathrm{MHz}$. b) Data for $\mathrm{C}_{5} \mathrm{D}_{5} \mathrm{~N}$ without $\mathrm{D}_{2} \mathrm{O}$ at $\left.\left.100 \mathrm{MHz} .<\mathrm{i}>\mathrm{c}</ \mathrm{i}>\right),<\mathrm{i}>\mathrm{d}</ \mathrm{i}>\right),<\mathrm{i}>\mathrm{e}</ \mathrm{i}>$ ). The signals with the same superscripts in each column may be interchangeable.

\section{Materials and Methods}

\subsection{Plant Material}

Leaves of S. cochinchinensis var. philippinensis were collected in Taketomi-cho, Yaeyama-gun, Okinawa, Japan, in November, 2003, and a voucher specimen was deposited in the Herbarium of Pharmaceutical Sciences, Graduate School of Biomedical Sciences, Hiroshima University (03-SC-Okinawa-1105).

\subsection{General Experimental Procedure}

Optical rotations were measured on a JASCO P-1030 digital polarimeter. IR and UV spectra were measured on Horiba FT-710 and JASCO V-520 UV/Vis spectrophotometers, respectively. ${ }^{1} \mathrm{H}$ - and ${ }^{13} \mathrm{C}-\mathrm{NMR}$ spectra were taken on JEOL JNM $\alpha-400$ and ECA-600 spectrometers at $400 \mathrm{MHz}$ or $600 \mathrm{MHz}$ and $100 \mathrm{MHz}$ or $150 \mathrm{MHz}$, respectively, with tetramethylsilane as an internal standard. CD spectra were obtained with a JASCO J-720 spectropolarimeter. Positive-ion HR-ESI-MS was performed with an Applied Biosystems QSTAR ${ }^{\circledR}$ XL NanoSprayTM System.

A highly-porous synthetic resin (Diaion HP-20) was purchased from Mitsubishi Kagaku (Tokyo, Japan). Silica gel CC was performed on silica gel 60 (E. Merck, Darmstadt, Germany), and ODS open CC on Cosmosil $75 \mathrm{C}_{18}$-OPN (Nacalai Tesque, Kyoto) $[\Phi=50 \mathrm{~mm}, L=25$ $\mathrm{cm}$, linear gradient: $\mathrm{MeOH}-\mathrm{H}_{2} \mathrm{O}(1: 9,11) \rightarrow(1: 1,11)$, fractions of $10 \mathrm{~g}$ being collected]. The DCCC (Tokyo Rikakikai, Tokyo, Japan) was equipped with 500 glass columns ( $\Phi=2 \mathrm{~mm}, L=40 \mathrm{~cm}$ ), the lower and upper layers of a solvent mixture of $\mathrm{CHCl}_{3}-\mathrm{MeOH}-\mathrm{H}_{2} \mathrm{O}-n$ PrOH (9:12:8:2) being used as the stationary and mobile phases, respectively. Five-gram fractions were collected and numbered according to their order of elution with the mobile phase. HPLC was performed on an ODS column (Inertsil; GL Science, Tokyo, Japan; $\Phi=20 \mathrm{~mm}, L=250$ $\mathrm{mm}, 6 \mathrm{ml} / \mathrm{min}$ ), and the eluate was monitored with a UV detector at $254 \mathrm{~nm}$, and a refractive index monitor. Crude hesperidinase was a generous gift from Tanabe Pharmaceutical Company Ltd. $(R)-(+)-$ and $(S)-(-)-\alpha-$ methoxy- $\alpha-$ trifluoromethylpheylacetic acids (MTPAs) were purchased from Nacalai Tesque Inc. (Kyoto, Japan). Authentic D-apiose $\left[[\alpha]_{\mathrm{D}}^{23}+9.4\left(c=0.84, \mathrm{H}_{2} \mathrm{O}\right)\right]$ was obtained by chromatographic separation of the hydrolyzate of apiin, isolated from commercial parsley (Petroselinum crispum). D-Apiose was identified by NMR spectroscopy [17].

\subsection{Extraction and Isolation}

Leaves of S. cochinchinensis var. phillipinensis $(10.8 \mathrm{~kg})$ were extracted three times with $\mathrm{MeOH}(451 \times 3)$ at room 
temperature for one week and then concentrated to $61 \mathrm{in}$ vacuo. The concentrated extract was washed with $n$ hexane $(61,150 \mathrm{~g})$ and then the $\mathrm{MeOH}$ layer was concentrated to a gummy mass. The latter was suspended in water $\left(\begin{array}{ll}6 & 1\end{array}\right)$ and then extracted with EtOAc (6 1) to give $107 \mathrm{~g}$ of an EtOAc-soluble fraction. The aqueous layer was extracted with 1-BuOH (6 1) to give a 1-BuOHsoluble fraction (247 g), and the remaining water-layer was concentrated to furnish $494 \mathrm{~g}$ of a water-soluble fraction. The 1-BuOH-soluble fraction (119 g) was subjected to Diaion HP-20 CC ( $\Phi=50 \mathrm{~mm}, L=50 \mathrm{~cm})$, using $\mathrm{H}_{2} \mathrm{O}-\mathrm{MeOH}(4: 1,4$ 1), $(3: 2,41),(2: 3,4$ 1), and $(1: 4$, 4 1), and $\mathrm{MeOH}(3 \mathrm{l}), 500 \mathrm{ml}$ fractions being collected. The residue $(12.5 \mathrm{~g}$ in fractions $11-18)$ of the $20 \%$ $40 \% \mathrm{MeOH}$ eluate obtained on HP-20 CC was subjected to silica gel $(500 \mathrm{~g}) \mathrm{CC}$ with increasing amounts of $\mathrm{MeOH}$ in $\mathrm{CHCl}_{3}\left[\mathrm{CHCl}_{3}(3 \mathrm{l})\right.$, and $\mathrm{CHCl}_{3}-\mathrm{MeOH}(99: 1$, 3 1), (97:3, 3 1), (19:1, 3 1), (37:3, 31$),(9: 1,31),(7: 1,31)$, $(17: 3,31),(33: 7,31),(4: 1,31),(3: 1,31)$ and $(7: 3,31)]$, and $\mathrm{CHCl}_{3}-\mathrm{MeOH}-\mathrm{H}_{2} \mathrm{O}(70: 30: 4,3 \mathrm{l}), 500 \mathrm{ml}$ fractions being collected. The residue (2.52 g) in fractions $39-49$ was separated by ODS open $\mathrm{CC}$ and then the residue (996 $\mathrm{mg}$ ) in fractions $56-81$ was subjected to DCCC. The residue $(130 \mathrm{mg})$ in fractions 75 - 88 was purified by HPLC (MeOH: $\left.\mathrm{H}_{2} \mathrm{O}, 1: 3\right)$ to give $85.7 \mathrm{mg}$ of 11 from the peak at $10 \mathrm{~min}$. The residue $(2.18 \mathrm{~g})$ in fractions $50-63$, obtained on silica gel CC, was separated by ODS open $\mathrm{CC}$ to give three subfractions (1.02 $\mathrm{g}$ in fractions $42-67$, $347 \mathrm{mg}$ in fractions $68-87$ and $138 \mathrm{mg}$ in fractions $110-$ 140). The first subfraction was separated again by DCCC to give a residue $(877 \mathrm{mg})$ in fractions $39-60$, which was then purified by HPLC (MeOH: $\left.\mathrm{H}_{2} \mathrm{O}, 1: 4\right)$ to afford $6.2 \mathrm{mg}$ of 9 and $11.2 \mathrm{mg}$ of 3 from the peaks at $35 \mathrm{~min}$ and $45 \mathrm{~min}$, respectively. The second subfraction was separated by DCCC to give a residue $(105 \mathrm{mg})$ in fractions 34 - 42, which was purified by HPLC $\left(\mathrm{MeOH}: \mathrm{H}_{2} \mathrm{O}\right.$, $2: 5$ ) to yield $23.9 \mathrm{mg}$ of 2 from the peak at $14 \mathrm{~min}$. The last subfraction was separated by DCCC to give a residue $(88.1 \mathrm{mg})$ in fractions $16-32$, which was purified by HPLC (MeOH: $\left.\mathrm{H}_{2} \mathrm{O}, 9: 20\right)$ to give $12.3 \mathrm{mg}$ of 1 from the peak at $22 \mathrm{~min}$.

The residue (19.7 $\mathrm{g}$ in fractions 19 - 25) of the $40 \%$ $60 \% \mathrm{MeOH}$ eluate obtained on HP-20 CC was subjected to silica gel $(500 \mathrm{~g}) \mathrm{CC}$ with increasing amounts of $\mathrm{MeOH}$ in $\mathrm{CHCl}_{3}\left[\mathrm{CHCl}_{3}\right.$ (3 1), and $\mathrm{CHCl}_{3}-\mathrm{MeOH}$ (99:1, 3 1), (97:3, 3 1), (19:1, 3 1), (37:3, 31$),(9: 1,31),(7: 1,31)$, $(17: 3,31),(33: 7,31),(4: 1,31),(3: 1,31)$ and $(7: 3,31)]$, and $\mathrm{CHCl}_{3}-\mathrm{MeOH}-\mathrm{H}_{2} \mathrm{O}(70: 30: 4,3$ 1), $500 \mathrm{ml}$ fractions being collected. The residue $(221 \mathrm{mg})$ in fractions $8-14$ was purified by HPLC (MeOH: $\left.\mathrm{H}_{2} \mathrm{O}, 3: 10\right)$, to give 2.0 $\mathrm{mg}$ of 8 from the peak at $44 \mathrm{~min}$. The residue $(115 \mathrm{mg})$ in fractions 16 - 25 was purified by $\mathrm{HPLC}\left(\mathrm{MeOH}: \mathrm{H}_{2} \mathrm{O}\right.$,
$3: 10)$ to give $4.8 \mathrm{mg}$ of 7 . The residue $(2.94 \mathrm{~g})$ in fractions 17 - 43 was separated by ODS open CC to give two subfractions (332 mg in fractions $61-63$ and $541 \mathrm{mg}$ in fractions 84 - 99). The former was separated by DCCC and then the residue $(16.8 \mathrm{mg})$ in fractions 47 - 54 was purified by HPLC (MeOH: $\left.\mathrm{H}_{2} \mathrm{O}, 1: 4\right)$ to give $2.8 \mathrm{mg}$ of 10 from the peak at $16 \mathrm{~min}$. The latter was separated by DCCC and then the residue (194 mg) in fractions $67-84$ was purified by HPLC (MeOH: $\left.\mathrm{H}_{2} \mathrm{O}, 7: 20\right)$ to afford 11.9 $\mathrm{mg}$ of 4 from the peak at $13 \mathrm{~min}$. The residue $(2.92 \mathrm{~g})$ in fractions 44 - 60, obtained on silica gel $\mathrm{CC}$, was subjected to ODS open $\mathrm{CC}$ to give a residue $(495 \mathrm{mg})$ in fractions 130 - 170. This residue was separated by DCCC to give two subfactions (136 mg in fractions $16-21$ and $189 \mathrm{mg}$ in fractions 22 - 41). The former was purified by HPLC (MeOH: $\left.\mathrm{H}_{2} \mathrm{O}, 2: 3\right)$ to give $20.0 \mathrm{mg}$ of 12 from the peak at $6 \mathrm{~min}$. The latter was also purified by HPLC (MeOH: $\left.\mathrm{H}_{2} \mathrm{O}, 9: 20\right)$ to give $23.0 \mathrm{mg}$ of 5 at $10 \mathrm{~min}$. The residue $(2.37 \mathrm{~g})$ in fractions $61-72$, obtained on silica gel $\mathrm{CC}$, was subjected to ODS open $\mathrm{CC}$ to give a residue (492 mg) in fractions 154 - 172, which was then separated by DCCC to give $82.9 \mathrm{mg}$ of 6 in fractions $29-42$.

\subsection{Symplocosionoside A (1)}

Amorphous powder, $[\alpha]_{\mathrm{D}}^{25}-44.0(c=0.82, \mathrm{MeOH})$; IR $v_{\max }$ (film): 3394, 2962, 2927, 2877, 1650, 1055, 1014 $\mathrm{cm}^{-1} ;{ }^{1} \mathrm{H}-\mathrm{NMR}\left(\mathrm{CD}_{3} \mathrm{OD}, 400 \mathrm{MHz}\right) \delta: 5.45$ (1H, dd, $J=$ 15, $6 \mathrm{~Hz}, \mathrm{H}-8), 5.28$ (1H, dd, $J=15,10 \mathrm{~Hz}, \mathrm{H}-7), 5.00$ $\left(1 \mathrm{H}, \mathrm{d}, J=2 \mathrm{~Hz}, \mathrm{H}-1^{\prime \prime}\right), 4.33$ (1H, d, $\left.J=8 \mathrm{~Hz}, \mathrm{H}-1^{\prime}\right), 4.21$ (1H, qd, $J=6,6 \mathrm{~Hz}, \mathrm{H}-9), 3.96$ (1H, $J=10 \mathrm{~Hz}, \mathrm{H}-4 " \mathrm{a})$, 3.94 (1H, dd, $J=12,2 \mathrm{~Hz}, \mathrm{H}-6 \mathrm{a}), 3.87(1 \mathrm{H}, \mathrm{d}, J=2 \mathrm{~Hz}$, H-2"), 3.83 (1H, dddd, $J=12,12,4,4$ Hz, H-3), 3.78 $(1 \mathrm{H}, \mathrm{d}, J=10 \mathrm{~Hz}, \mathrm{H}-4 " \mathrm{~b}), 3.59$ (1H, dd, $J=12,6 \mathrm{~Hz}, \mathrm{H}-$ 6'b), 3.54 (2H, s, $\left.\mathrm{H}_{2}-5^{\prime \prime}\right), 3.39$ (1H, ddd, $J=9,6,2 \mathrm{~Hz}$, H-5'), 3.34 (1H, dd, $J=9,9$ Hz, H-3'), 3.25 (1H, dd, $J=$ 9, $\left.9 \mathrm{~Hz}, \mathrm{H}-4^{\prime}\right), 3.11$ (1H, dd, $\left.J=9,8 \mathrm{~Hz}, \mathrm{H}-2^{\prime}\right), 2.12(1 \mathrm{H}$, dddd, $J=12,4,4,2 \mathrm{~Hz}, \mathrm{H}-4 \mathrm{eq}), 1.83$ (1H, ddd, $J=12,4$, $2 \mathrm{~Hz}, \mathrm{H}-2 \mathrm{eq}), 1.52$ (1H, m, H-5), 1.30 (1H, dd, $J=10,10$ $\mathrm{Hz}, \mathrm{H}-6), 1.21$ (3H, d, $\left.J=6 \mathrm{~Hz}, \mathrm{H}_{3}-10\right), 1.16$ (1H, dd, $J=$ $12,12 \mathrm{~Hz}, \mathrm{H}-2 \mathrm{ax}), 1.10$ (1H, ddd, $J=12,12,12 \mathrm{~Hz}, \mathrm{H}-$ $4 \mathrm{ax}), 0.91\left(3 \mathrm{H}, \mathrm{s}, \mathrm{H}_{3}-11\right), 0.87\left(3 \mathrm{H}, \mathrm{s}, \mathrm{H}_{3}-12\right), 0.83(3 \mathrm{H}$, $\left.\mathrm{d}, J=7 \mathrm{~Hz}, \mathrm{H}_{3}-13\right)$; ${ }^{13} \mathrm{C}-\mathrm{NMR}\left(\mathrm{CD}_{3} \mathrm{OD}, 100 \mathrm{MHz}\right)$ : Table 1; HR-ESI-MS (positive-ion mode) $\mathrm{m} / \mathrm{z}: 529.2620$ $[\mathrm{M}+\mathrm{Na}]^{+}\left(\right.$Calcd for $\left.\mathrm{C}_{24} \mathrm{H}_{42} \mathrm{O}_{11} \mathrm{Na}: 529.2619\right)$.

\subsection{Symplocosionoside B (2)}

Amorphous powder, $[\alpha]_{\mathrm{D}}{ }^{26}-63.0(c=1.59, \mathrm{MeOH})$; IR $v_{\max }$ (film): 3399, 2969, 2931, 2880, 1694, 1651, 1150, $1056 \mathrm{~cm}^{-1}$; ${ }^{1} \mathrm{H}-\mathrm{NMR}\left(\mathrm{CD}_{3} \mathrm{OD}, 400 \mathrm{MHz}\right) \delta: 5.89(1 \mathrm{H}, \mathrm{dd}$, $J=16,6 \mathrm{~Hz}, \mathrm{H}-8), 5.74(1 \mathrm{H}, \mathrm{d}, J=16 \mathrm{~Hz}, \mathrm{H}-7), 4.98$ (1H, d, $J=2 \mathrm{~Hz}, \mathrm{H}-1 "), 4.43$ (1H, qd, $J=6,6 \mathrm{~Hz}, \mathrm{H}-9)$, 4.34 (1H, d, $J=8$ Hz, H-1'), 3.97 (1H, d, $J=10$ Hz, H- 
4"a), 3.94 (1H, dd, $J=12,2 \mathrm{~Hz}, \mathrm{H}-6$ 'a), 3.91 (1H, d, $J=$ $2 \mathrm{~Hz}, \mathrm{H}-2 "), 3.75(1 \mathrm{H}, \mathrm{d}, J=10 \mathrm{~Hz}, \mathrm{H}-4 " \mathrm{~b}), 3.58(1 \mathrm{H}, \mathrm{dd}$, $\left.J=12,6 \mathrm{~Hz}, \mathrm{H}-6^{\prime} \mathrm{b}\right), 3.57$ (2H, s, $\left.\mathrm{H}_{2}-5 "\right), 3.34$ (1H, m, H$\left.5^{\prime}\right), 3.32\left(1 \mathrm{H}, \mathrm{m}, \mathrm{H}-3^{\prime}\right), 3.29$ (1H, dd, $\left.J=9,9, \mathrm{H}-4^{\prime}\right), 3.18$ $(1 \mathrm{H}, \mathrm{dd}, J=9,8 \mathrm{~Hz}, \mathrm{H}-2), 2.87(1 \mathrm{H}, \mathrm{d}, J=14 \mathrm{~Hz}, \mathrm{H}-$ 2ax), $2.44(1 \mathrm{H}, \mathrm{dd}, J=14,14 \mathrm{~Hz}, \mathrm{H}-4 \mathrm{ax}), 2.28(1 \mathrm{H}, \mathrm{dqd}$, $J=14,7,4 \mathrm{~Hz}, \mathrm{H}-5), 2.12$ (1H, ddd, $J=14,4,2 \mathrm{~Hz}, \mathrm{H}-$ 4eq), 1.82 (1H, dd, $J=14,2 \mathrm{~Hz}, \mathrm{H}-2 \mathrm{eq}), 1.32$ (3H, d, $J=$ $\left.6 \mathrm{~Hz}, \mathrm{H}_{3}-10\right), 0.99$ (3H, s, $\left.\mathrm{H}_{3}-11\right), 0.93\left(3 \mathrm{H}, \mathrm{s}, \mathrm{H}_{3}-12\right)$, $0.90\left(3 \mathrm{H}, \mathrm{d}, J=7 \mathrm{~Hz}, \mathrm{H}_{3}-13\right) ;{ }^{13} \mathrm{C}-\mathrm{NMR}\left(\mathrm{CD}_{3} \mathrm{OD}, 100\right.$ MHz): Table 1; CD $(\mathrm{MeOH}) \mathrm{nm}(\Delta \varepsilon)$ : $289(+0.89), 246$ $(+0.63)\left(c=2.51 \times 10^{-5} \mathrm{M}\right)$; HR-ESI-MS (positive-ion mode) $m / z$ : $543.2404[\mathrm{M}+\mathrm{Na}]^{+}\left(\right.$Calcd for $\mathrm{C}_{24} \mathrm{H}_{40} \mathrm{O}_{12} \mathrm{Na}$ : 543.2411).

\subsection{Symplocosionoside C (3)}

Amorphous powder, $[\delta]_{\mathrm{D}}{ }^{25}-57.9(c=0.61, \mathrm{MeOH}) ; \mathrm{IR}$ $v_{\max }$ (film): 3399, 3366, 2958, 2927, 1938, 1669, 1515, $1366,1243,1069,1042 \mathrm{~cm}^{-1}$; UV $\lambda_{\max }(\mathrm{MeOH}) \mathrm{nm}(\log$ ع): 321 (4.53), 283 (3.91), 220 (4.04); ${ }^{1} \mathrm{H}-\mathrm{NMR}\left(\mathrm{CD}_{3} \mathrm{OD}\right.$, $400 \mathrm{MHz}) \delta: 5.96(1 \mathrm{H}, \mathrm{s}, \mathrm{H}-8), 4.52(1 \mathrm{H}, \mathrm{d}, J=8 \mathrm{~Hz}, \mathrm{H}-$ 1'), $4.31(1 \mathrm{H}, \mathrm{dddd}, J=12,12,4,4 \mathrm{~Hz}, \mathrm{H}-3), 4.27(1 \mathrm{H}, \mathrm{d}$, $J=7 \mathrm{~Hz}, \mathrm{H}-1 "), 4.00$ (1H, dd, $J=11,2 \mathrm{~Hz}, \mathrm{H}-6 \mathrm{a}), 3.85$ (1H, dd, $J=12,4 \mathrm{~Hz}, \mathrm{H}-5 " \mathrm{a}), 3.81$ (1H, m, H-4"), 3.69 $(1 \mathrm{H}, \mathrm{dd}, J=11,5 \mathrm{~Hz}, \mathrm{H}-6 \mathrm{\prime}), 3.64(1 \mathrm{H}, \mathrm{dd}, J=8,7 \mathrm{~Hz}$, H-2"), 3.54 (1H, m, H-3"), 3.53 (1H, dd, $J=12,3 \mathrm{~Hz}, \mathrm{H}-$ $5 " \mathrm{~b}), 3.37$ (1H, m, H-5'), 3.35 (1H, dd, $\left.J=9,9 \mathrm{~Hz}, \mathrm{H}-4{ }^{\prime}\right)$, $3.33(1 \mathrm{H}, \mathrm{dd}, J=9,9 \mathrm{~Hz}, \mathrm{H}-3$ '), $3.14(1 \mathrm{H}, \mathrm{dd}, J=9,8 \mathrm{~Hz}$, H-2'), 2.48 (1H, ddd, $J=12,4,2 \mathrm{~Hz}, \mathrm{H}-4 \mathrm{eq}), 2.19$ (3H, s, $\left.\mathrm{H}_{3}-10\right), 1.91$ (1H, ddd, $\left.J=12,4,2 \mathrm{~Hz}, \mathrm{H}-2 \mathrm{eq}\right), 1.47(3 \mathrm{H}$, s, $\left.\mathrm{H}_{3}-13\right), 1.37\left(3 \mathrm{H}, \mathrm{s}, \mathrm{H}_{3}-11\right), 1.36(1 \mathrm{H}, \mathrm{dd}, J=12,12$ $\mathrm{Hz}, \mathrm{H}-4 \mathrm{ax}), 1.34(1 \mathrm{H}, \mathrm{dd}, J=12,12 \mathrm{~Hz}, \mathrm{H}-2 \mathrm{ax}), 1.16$ $\left(3 \mathrm{H}, \mathrm{s}, \mathrm{H}_{3}-12\right) ;{ }^{13} \mathrm{C}-\mathrm{NMR}\left(\mathrm{CD}_{3} \mathrm{OD}\right.$ and $\mathrm{C}_{5} \mathrm{D}_{5} \mathrm{~N}, 100$ MHz): Table 1; CD $(\mathrm{MeOH}) \mathrm{nm}(\Delta \varepsilon): 319$ (-0.47), 263 $(-2.87), 207(-23.1)\left(c=3.41 \times 10^{-5} \mathrm{M}\right)$. HR-ESI-MS (positive-ion mode) $\mathrm{m} / \mathrm{z}: 541.2257[\mathrm{M}+\mathrm{Na}]^{+}$(Calcd for $\mathrm{C}_{24} \mathrm{H}_{38} \mathrm{O}_{12} \mathrm{Na}$ : 541.2255).

\subsection{Symplocosneolignan (4)}

Amorphous powder, $[\alpha]_{\mathrm{D}}^{25}-13.5(c=0.79, \mathrm{MeOH})$; IR $v_{\max }$ (film): 3395, 2939, 1592, 1419, 1328, 1229, 1123, $1061 \mathrm{~cm}^{-1}$; UV $\lambda_{\max }(\mathrm{MeOH}) \mathrm{nm}(\log \varepsilon): 269$ (3.59), 213 (4.31); ${ }^{1} \mathrm{H}-\mathrm{NMR}\left(\mathrm{CD}_{3} \mathrm{OD}, 400 \mathrm{MHz}\right)$ : Table $2 ;{ }^{13} \mathrm{C}-$ NMR $\left(\mathrm{CD}_{3} \mathrm{OD}, 100 \mathrm{MHz}\right)$ : Table 2; $\mathrm{CD}(\mathrm{MeOH}) \mathrm{nm}$ $(\Delta \varepsilon): 304(+1.71), 242(-4.67)\left(c=4.00 \times 10^{-5} \mathrm{M}\right)$; HRESI-MS (positive-ion mode) $\mathrm{m} / \mathrm{z}: 623.2294[\mathrm{M}+\mathrm{Na}]^{+}$ (Calcd for $\mathrm{C}_{28} \mathrm{H}_{40} \mathrm{O}_{14} \mathrm{Na}$ : 623.2310).

\subsection{Symplocoside A (5)}

Amorphous powder, $[\alpha]_{\mathrm{D}}{ }^{22}+14.8(c=0.54, \mathrm{MeOH})$; IR $v_{\max }$ (film): 3382, 2930, 2882, 1730, 1635, 1140, 1074, $1036 \mathrm{~cm}^{-1} ;{ }^{1} \mathrm{H}-\mathrm{NMR}\left(\mathrm{C}_{5} \mathrm{D}_{5} \mathrm{~N}+\right.$ one drop of $\mathrm{D}_{2} \mathrm{O}, 600$
MHz) $\delta: 6.07\left(1 \mathrm{H}, \mathrm{d}, J=8 \mathrm{~Hz}, \mathrm{H}-1^{\prime}\right), 5.50(1 \mathrm{H}, \mathrm{dd}, J=4$, $4 \mathrm{~Hz}, \mathrm{H}-12), 5.14$ (1H, d, $J=7 \mathrm{~Hz}, \mathrm{H}-1 "), 4.44$ (1H, dd, $J$ = 9, $7 \mathrm{~Hz}, \mathrm{H}-2 "), 4.40$ (2H, dd, $J=14,2 \mathrm{~Hz}, \mathrm{H}-6 \mathrm{\prime a}), 4.28$ $\left(1 \mathrm{H}, \mathrm{dd}, J=9,9 \mathrm{~Hz}, \mathrm{H}-3^{\prime}\right), 4.27$ (1H, m, H-6'b and 5"a), $4.26\left(2 \mathrm{H}, \mathrm{m}, \mathrm{H}-2^{\prime}\right.$ and $\left.4^{\prime \prime}\right), 4.19$ (2H, m, H-2 and 4'), 4.14 $(1 \mathrm{H}, \mathrm{dd}, J=9,3 \mathrm{~Hz}, \mathrm{H}-3 "), 4.10(1 \mathrm{H}, \mathrm{d}, J=10 \mathrm{~Hz}, \mathrm{H}-3)$, $4.05(1 \mathrm{H}, \mathrm{d}, J=11 \mathrm{~Hz}, \mathrm{H}-23 \mathrm{a}), 3.94(1 \mathrm{H}, \mathrm{ddd}, J=9,5,2$ Hz, H-5'), 3.71 (1H, dd, $J=13,2 \mathrm{~Hz}, \mathrm{H}-5 " \mathrm{~b}), 3.58$ (1H, d, $J=11 \mathrm{~Hz}, \mathrm{H}-23 \mathrm{~b}), 2.99(1 \mathrm{H}, \mathrm{ddd}, J=13,13,5 \mathrm{~Hz}, \mathrm{H}-$ 16a), $2.86(1 \mathrm{H}$, br s, H-18), $2.24(1 \mathrm{H}, \mathrm{dd}, J=12,4 \mathrm{~Hz}$, H-1a), 2.30 (1H, ddd, $J=14,13,5 \mathrm{~Hz}, \mathrm{H}-15 \mathrm{a}), 2.07(2 \mathrm{H}$, $\left.\mathrm{m}, \mathrm{H}_{2}-11\right), 2.02(1 \mathrm{H}, \mathrm{m}, \mathrm{H}-16 \mathrm{~b}), 1.97$ (3H, m, H-21a and $\left.\mathrm{H}_{2}-22\right), 1.96(1 \mathrm{H}, \mathrm{m}, \mathrm{H}-9), 1.78(1 \mathrm{H}, \mathrm{m}, \mathrm{H}-7 \mathrm{a}), 1.70(1 \mathrm{H}$, br d, $J=12 \mathrm{~Hz}, \mathrm{H}-5), 1.60$ (2H, m, H-6a and $7 \mathrm{~b}), 1.57$ (3H, s, $\left.\mathrm{H}_{3}-27\right), 1.43(1 \mathrm{H}, \mathrm{m}, \mathrm{H}-20), 1.38\left(3 \mathrm{H}, \mathrm{s}, \mathrm{H}_{3}-29\right)$, $1.34(1 \mathrm{H}, \mathrm{m}, \mathrm{H}-6 \mathrm{~b}), 1.32(1 \mathrm{H}, \mathrm{m}, \mathrm{H}-15 \mathrm{~b}), 1.24(1 \mathrm{H}, \mathrm{m}$, $\mathrm{H}-21 \mathrm{~b}), 1.30(1 \mathrm{H}, \mathrm{m}, \mathrm{H}-1 \mathrm{~b}), 1.09\left(3 \mathrm{H}, \mathrm{s}, \mathrm{H}_{3}-26\right), 1.06$ $\left(3 \mathrm{H}, \mathrm{d}, J=7 \mathrm{~Hz}, \mathrm{H}_{3}-30\right), 1.05$ (3H, s, $\left.\mathrm{H}_{3}-25\right), 0.96(3 \mathrm{H}, \mathrm{s}$, $\left.\mathrm{H}_{3}-24\right) ;{ }^{13} \mathrm{C}-\mathrm{NMR}\left(\mathrm{C}_{5} \mathrm{D}_{5} \mathrm{~N}, 100 \mathrm{MHz}\right)$ : Table 3; HR-ESIMS (positive-ion mode) $m / z: 821.4277[\mathrm{M}+\mathrm{Na}]^{+}$(Calcd for $\mathrm{C}_{41} \mathrm{H}_{66} \mathrm{O}_{15} \mathrm{Na}$ : 821.4293).

\subsection{Symplocoside B (6)}

Amorphous powder, $[\alpha]_{\mathrm{D}}^{22}+9.1(c=1.22, \mathrm{MeOH})$; IR $v_{\max }$ (film): 3395, 2931, 2883, 1730, 1647, 1156, 1076, $1035 \mathrm{~cm}^{-1}$; ${ }^{1} \mathrm{H}-\mathrm{NMR}\left(\mathrm{C}_{5} \mathrm{D}_{5} \mathrm{~N}+\right.$ one drop of $\mathrm{D}_{2} \mathrm{O}, 600$ MHz) $\delta: 6.07$ (1H, d, $\left.J=8 \mathrm{~Hz}, \mathrm{H}-1^{\prime}\right), 5.49$ (1H, dd, $J=4$, $4 \mathrm{~Hz}, \mathrm{H}-12), 5.38$ (1H, d, $J=8 \mathrm{~Hz}, \mathrm{H}-1 "), 5.28(1 \mathrm{H}, \mathrm{d}, J$ $\left.=8 \mathrm{~Hz}, \mathrm{H}-1^{\prime \prime \prime}\right), 4.48(1 \mathrm{H}, \mathrm{dd}, J=12,2 \mathrm{~Hz}, \mathrm{H}-6 \mathrm{a}), 4.35$ $\left(1 \mathrm{H}, \mathrm{dd}, J=9,8 \mathrm{~Hz}, \mathrm{H}-2^{\prime}\right), 4.32(1 \mathrm{H}, \mathrm{dd}, J=12,2 \mathrm{~Hz}, \mathrm{H}-$ 6"'a), 4.31 (1H, m, H-2"), 4.28 (1H, dd, $\left.J=9,9 \mathrm{~Hz}, \mathrm{H}-3^{\prime}\right)$, 4.20 (2H, m, H-5"a and H-6"'b), 4.18 (1H, m, H-2), 4.16 (3H, m, H-4', 4" and 3"'), $4.15(1 \mathrm{H}, \mathrm{m}, \mathrm{H}-6 \mathrm{'b}), 4.10(1 \mathrm{H}$, dd, $J=9,3 \mathrm{~Hz}, \mathrm{H}-3 "), 4.09(1 \mathrm{H}, \mathrm{d}, J=9 \mathrm{~Hz}, \mathrm{H}-3), 4.04$ $\left(1 \mathrm{H}, \mathrm{dd}, J=9,9 \mathrm{~Hz}, \mathrm{H}-4{ }^{\prime \prime}\right), 4.03(1 \mathrm{H}, \mathrm{d}, J=11 \mathrm{~Hz}, \mathrm{H}-$ 23a), 3.98 (1H, dd, $J=9,8 \mathrm{~Hz}, \mathrm{H}-2 " '), 3.94$ (1H, ddd, $J=$ 9, 6, $2 \mathrm{~Hz}, \mathrm{H}-5$ "') $^{\prime} 3.89$ (1H, ddd, $\left.J=9,5,2 \mathrm{~Hz}, \mathrm{H}-5^{\prime}\right)$, $3.64(1 \mathrm{H}$, br d, $J=12 \mathrm{~Hz}, \mathrm{H}-5 "), 3.54(1 \mathrm{H}, \mathrm{d}, J=11 \mathrm{~Hz}$, H-23b), $2.99(1 \mathrm{H}$, ddd, $J=13,13,5 \mathrm{~Hz}, \mathrm{H}-16 \mathrm{a}), 2.87$ (1H, br s, H-18), $2.27(1 \mathrm{H}, \mathrm{m}, \mathrm{H}-15 \mathrm{a}), 2.24(1 \mathrm{H}, \mathrm{dd}, J=$ 12, $4 \mathrm{~Hz}, \mathrm{H}-1 \mathrm{a}), 2.16(1 \mathrm{H}$, br d, $J=13 \mathrm{~Hz}, \mathrm{H}-16 \mathrm{~b}), 2.07$ $\left(2 \mathrm{H}, \mathrm{m}, \mathrm{H}_{2}-11\right), 1.98(1 \mathrm{H}, \mathrm{m}, \mathrm{H}-21 \mathrm{a}), 1.97\left(2 \mathrm{H}, \mathrm{m}, \mathrm{H}_{2^{-}}\right.$ 22), $1.96(1 \mathrm{H}, \mathrm{m}, \mathrm{H}-9), 1.77$ (1H, ddd, $J=13,13,4 \mathrm{~Hz}$, $\mathrm{H}-7 \mathrm{a}), 1.67(1 \mathrm{H}$, br d, $J=12 \mathrm{~Hz}, \mathrm{H}-5), 1.65(1 \mathrm{H}, \mathrm{ddd}, J$ $=13,2,2 \mathrm{~Hz}, \mathrm{H}-7 \mathrm{~b}), 1.57\left(3 \mathrm{H}, \mathrm{s}, \mathrm{H}_{3}-27\right), 1.56(1 \mathrm{H}, \mathrm{m}$, H-6a), 1.48 (1H, m, H-15b), 1.46 (1H, m, H-20), 1.37 (3H, s, $\left.\mathrm{H}_{3}-29\right), 1.31(1 \mathrm{H}, \mathrm{m}, \mathrm{H}-6 \mathrm{~b}), 1.29(1 \mathrm{H}, \mathrm{m}, \mathrm{H}-1 \mathrm{~b})$, $1.26(1 \mathrm{H}, \mathrm{m}, \mathrm{H}-21 \mathrm{~b}), 1.12\left(3 \mathrm{H}, \mathrm{s}, \mathrm{H}_{3}-26\right), 1.06(3 \mathrm{H}, \mathrm{d}, J$ $\left.=7 \mathrm{~Hz}, \mathrm{H}_{3}-30\right), 1.04\left(3 \mathrm{H}, \mathrm{s}, \mathrm{H}_{3}-25\right), 0.95\left(3 \mathrm{H}, \mathrm{s}, \mathrm{H}_{3}-24\right)$; ${ }^{13} \mathrm{C}-\mathrm{NMR}\left(\mathrm{C}_{5} \mathrm{D}_{5} \mathrm{~N}, 100 \mathrm{MHz}\right)$ : Table 3; HR-ESI-MS (positive-ion mode) $m / z$ : $983.4823[\mathrm{M}+\mathrm{Na}]^{+}$(Calcd for $\mathrm{C}_{47} \mathrm{H}_{76} \mathrm{O}_{20} \mathrm{Na}$ : 983.4822). 


\subsection{Enzymatic Hydrolysis of Symplocosionoside A (1)}

Symplocosionoside A (1) $(6.6 \mathrm{mg})$ in $2 \mathrm{ml}$ of $\mathrm{H}_{2} \mathrm{O}$ was hydrolyzed with emulsin $(14.2 \mathrm{mg})$ and crude hesperidinase $(6.0 \mathrm{mg})$ for $15 \mathrm{~h}$ at $37^{\circ} \mathrm{C}$. The reaction mixture was evaporated to dryness, and then the methanolic solution was absorbed on silica gel and subjected to silica gel $\mathrm{CC}(30 \mathrm{~g}, \Phi=18 \mathrm{~mm}, L=21 \mathrm{~cm})$ with $\mathrm{CHCl}_{3}(100 \mathrm{ml})$ and $\mathrm{CHCl}_{3}-\mathrm{MeOH}(19: 1,100 \mathrm{ml}, 9: 1,100 \mathrm{ml}, 17: 3,100$ $\mathrm{ml}$ and 7:3,300 ml), $12 \mathrm{ml}$ fractions being collected. An aglycone (1a) (1.8 mg, 65\%) was recovered in fractions 19 - 23. Aglycone (megastigman-7-ene-3,9-diol) (1a): Colorless syrup, $[\alpha]_{\mathrm{D}}^{29}-20.0 \quad(c=0.12, \mathrm{MeOH})$; ${ }^{1} \mathrm{H}-\mathrm{NMR}\left(\mathrm{CD}_{3} \mathrm{OD}, 400 \mathrm{MHz}\right) \delta: 5.45(1 \mathrm{H}, \mathrm{dd}, J=15$, $6 \mathrm{~Hz}, \mathrm{H}-8), 5.29(1 \mathrm{H}, \mathrm{dd}, J=15,10, \mathrm{H}-7), 4.21(1 \mathrm{H}$, qd, $J=6,6 \mathrm{~Hz}, \mathrm{H}-9$ ), 3.71 (1H, dddd, $J=12,12,4,4$ $\mathrm{Hz}, \mathrm{H}-3), 1.96$ (1H, dddd, $J=12,12,4,2 \mathrm{~Hz}, \mathrm{H}-4 \mathrm{eq})$, $1.70(1 \mathrm{H}, \mathrm{ddd}, J=12,4,2 \mathrm{~Hz}, \mathrm{H}-2 \mathrm{eq}), 1.52(1 \mathrm{H}, \mathrm{ddq}$, $J=12,10,7 \mathrm{~Hz}, \mathrm{H}-5), 1.30(1 \mathrm{H}, \mathrm{dd}, J=10,10 \mathrm{~Hz}$, H-6), $1.21\left(3 \mathrm{H}, \mathrm{d}, J=6 \mathrm{~Hz}, \mathrm{H}_{3}-10\right), 1.10(1 \mathrm{H}, \mathrm{dd}, J=$ $12,12 \mathrm{~Hz}, \mathrm{H}-2 \mathrm{ax}), 0.89(1 \mathrm{H}, \mathrm{ddd}, J=12,12,12 \mathrm{~Hz}$, $\mathrm{H}-4 \mathrm{ax}), 0.88\left(3 \mathrm{H}, \mathrm{s}, \mathrm{H}_{3}-12\right), 0.86\left(3 \mathrm{H}, \mathrm{s}, \mathrm{H}_{3}-11\right), 0.82$ $\left(3 \mathrm{H}, \mathrm{d}, J=7 \mathrm{~Hz}, \mathrm{H}_{3}-13\right) ;{ }^{13} \mathrm{C}-\mathrm{NMR}\left(\mathrm{CD}_{3} \mathrm{OD}, 100\right.$ MHz): Table 1; HR-ESI-MS (positive-ion mode) $\mathrm{m} / \mathrm{z}$ : $235.1661[\mathrm{M}+\mathrm{Na}]^{+}$(Calcd for $\mathrm{C}_{13} \mathrm{H}_{24} \mathrm{O}_{2} \mathrm{Na}$ : 235.1668).

\subsection{Preparation of (R)- and (S)-MPTA Diesters (1b and 1c) from 1a}

A solution of 1a $(0.7 \mathrm{mg})$ in $1 \mathrm{ml}$ of dehydrated $\mathrm{CH}_{2} \mathrm{Cl}_{2}$ was reacted with $(R)$-MTPA $(42 \mathrm{mg})$ in the presence of 1-ethyl-3-(3-dimethylaminopropyl)carbodiimide hydrochloride (EDC) $(31 \mathrm{mg})$ and $\mathrm{N}, \mathrm{N}$-dimethyl-4-aminopyridine (4-DMAP) $(31 \mathrm{mg})$, and then the mixture was occasionally stirred at $25^{\circ} \mathrm{C}$ for $30 \mathrm{~min}$. After the addition of $1 \mathrm{ml}$ of $\mathrm{CH}_{2} \mathrm{Cl}_{2}$, the solution was washed with $\mathrm{H}_{2} \mathrm{O}(1 \mathrm{ml}), 5 \% \mathrm{HCl}(1 \mathrm{ml}), \mathrm{NaHCO}_{3}$-saturated $\mathrm{H}_{2} \mathrm{O}$, and then brine $(1 \mathrm{ml})$, successively. The organic layer was dried over $\mathrm{Na}_{2} \mathrm{SO}_{4}$ and then evaporated under reduced pressure. The residue was purified by preparative TLC [silica gel $(0.25 \mathrm{~mm}$ thickness), being applied for $18 \mathrm{~cm}$, developed with $\mathrm{CHCl}_{3}-\left(\mathrm{CH}_{3}\right)_{2} \mathrm{CO}(19: 1)$ for $9 \mathrm{~cm}$, and then eluted with $\left.\mathrm{CHCl}_{3}-\mathrm{MeOH}(9: 1)\right]$ to furnish an ester, 1b $(1.5 \mathrm{mg}, 71 \%)$. Through a similar procedure, 1c (1.1 $\mathrm{mg}, 61 \%)$ was prepared from 1a $(0.6 \mathrm{mg})$ using $(S)$ MTPA (53 mg), EDC (41 mg), and 4-DMAP (24 mg). $(3 S, 5 R, 6 R, 7 E, 9 R)$-Megastigman-7-ene-3,9-diol 3,9$O$-(R)-MTPA diester (1b) An amorphous powder; ${ }^{1} \mathrm{H}-\mathrm{NMR}\left(\mathrm{CDCl}_{3}, 400 \mathrm{MHz}\right) \delta: 7.47$ - $7.43(4 \mathrm{H}, \mathrm{m}$, aromatic protons), $7.35-7.30(6 \mathrm{H}, \mathrm{m}$, aromatic protons), $5.56(1 \mathrm{H}, \mathrm{qd}, J=6,6 \mathrm{~Hz}, \mathrm{H}-9), 5.43(1 \mathrm{H}, \mathrm{m}, \mathrm{H}-8), 5.42$
(1H, m, H-7), 5.15 (1H, dddd, $J=12,12,4,4 \mathrm{~Hz}, \mathrm{H}-3)$, $3.48\left(3 \mathrm{H}\right.$, br s, $\left.-\mathrm{OCH}_{3}\right), 3.47\left(3 \mathrm{H}, \mathrm{br} \mathrm{s},-\mathrm{OCH}_{3}\right), 2.13(1 \mathrm{H}$, dddd, $J=12,4,4,2 \mathrm{~Hz}, \mathrm{H}-4 \mathrm{eq}), 1.76$ (1H, ddd, $J=12,4$, $2 \mathrm{~Hz}, \mathrm{H}-2 \mathrm{eq}), 1.68$ (1H, m, H-5), $1.43(1 \mathrm{H}, \mathrm{dd}, J=10,10$ $\mathrm{Hz}, \mathrm{H}-6), 1.36\left(3 \mathrm{H}, \mathrm{d}, J=6 \mathrm{~Hz}, \mathrm{H}_{3}-10\right), 1.16(1 \mathrm{H}, \mathrm{dd}, J=$ $12,12 \mathrm{~Hz}, \mathrm{H}-2 \mathrm{ax}), 0.99(1 \mathrm{H}, \mathrm{ddd}, J=12,12,12 \mathrm{~Hz}$, H-4ax), $0.88\left(3 \mathrm{H}, \mathrm{d}, J=6 \mathrm{~Hz}, \mathrm{H}_{3}-13\right), 0.84(3 \mathrm{H}, \mathrm{s}$, $\mathrm{H}_{3}-11$ ), 0.82 (3H, s, $\mathrm{H}_{3}-12$ ); HR-ESI-TOF-MS (positive-ion mode) $\mathrm{m} / \mathrm{z}$ : $667.2472[\mathrm{M}+\mathrm{Na}]^{+}$(Calcd for $\left.\mathrm{C}_{33} \mathrm{H}_{38} \mathrm{O}_{6} \mathrm{~F}_{6} \mathrm{Na}, 667.2464\right)$. (3S, 5R, 6R, 7E, 9R)- Megastigman-7-ene-3,9-diol 3,9-O-(S)-MTPA diester (1c) An amorphous powder; ${ }^{1} \mathrm{H}-\mathrm{NMR}\left(\mathrm{CDCl}_{3}, 400 \mathrm{MHz}\right) \delta: 7.47$ - $7.43(4 \mathrm{H}, \mathrm{m}$, aromatic protons), $7.35-7.30(6 \mathrm{H}, \mathrm{m}$, aromatic protons), $5.56(1 \mathrm{H}, \mathrm{qd}, J=6,6 \mathrm{~Hz}, \mathrm{H}-9), 5.39$ $(1 \mathrm{H}, \mathrm{m}, \mathrm{H}-8), 5.38(1 \mathrm{H}, \mathrm{m}, \mathrm{H}-7), 5.14(1 \mathrm{H}$, dddd, $J=12$, $12,4,4 \mathrm{~Hz}, \mathrm{H}-3), 3.48\left(3 \mathrm{H}, \mathrm{br} \mathrm{s},-\mathrm{OCH}_{3}\right), 3.46(3 \mathrm{H}$, br s, $\left.-\mathrm{OCH}_{3}\right), 2.04(1 \mathrm{H}$, dddd, $J=12,4,4,2 \mathrm{~Hz}, \mathrm{H}-4 \mathrm{eq}), 1.82$ $(1 \mathrm{H}$, ddd, $J=12,4,2 \mathrm{~Hz}, \mathrm{H}-2 \mathrm{eq}), 1.60(1 \mathrm{H}, \mathrm{m}, \mathrm{H}-5)$, $1.41\left(3 \mathrm{H}, \mathrm{d}, J=6 \mathrm{~Hz}, \mathrm{H}_{3}-10\right), 1.37(1 \mathrm{H}, \mathrm{dd}, J=10,10$ $\mathrm{Hz}, \mathrm{H}-6), 1.19(1 \mathrm{H}, \mathrm{dd}, J=12,12 \mathrm{~Hz}, \mathrm{H}-2 \mathrm{ax}), 0.88(1 \mathrm{H}$, ddd, $J=12,12,12 \mathrm{H}-4 \mathrm{ax}), 0.87\left(3 \mathrm{H}, \mathrm{s}, \mathrm{H}_{3}-11\right), 0.82(3 \mathrm{H}$, s, $\left.\mathrm{H}_{3}-12\right), 0.77\left(3 \mathrm{H}, \mathrm{d}, J=6 \mathrm{~Hz}, \mathrm{H}_{3}-13\right)$; HR-ESI-MS (positive-ion mode) $\mathrm{m} / \mathrm{z}$ : $667.2471[\mathrm{M}+\mathrm{Na}]^{+}(\mathrm{Calcd}$ for $\left.\mathrm{C}_{33} \mathrm{H}_{38} \mathrm{O}_{6} \mathrm{~F}_{6} \mathrm{Na}, 667.2464\right)$.

\subsection{Enzymatic Hydrolysis of Symplocosneolignan (4)}

Symplocosneolignan (4) $(4.7 \mathrm{mg})$ in $2 \mathrm{ml}$ of $\mathrm{H}_{2} \mathrm{O}$ was hydrolyzed with emulsin $(12 \mathrm{mg})$ and crude hesperidinase $(6.0 \mathrm{mg})$ for $15 \mathrm{~h}$ at $37^{\circ} \mathrm{C}$. The reaction mixture was evaporated to dryness, and then the methanolic solution was absorbed on silica gel and subjected to silica gel CC (30 g, $\Phi=18 \mathrm{~mm}, L=21 \mathrm{~cm})$ with $\mathrm{CHCl}_{3}(100 \mathrm{ml})$ and $\mathrm{CHCl}_{3}-\mathrm{MeOH}(19: 1,100 \mathrm{ml}, 9: 1,100 \mathrm{ml}, 17: 3,100 \mathrm{ml}$ and 7:3, $300 \mathrm{ml}), 12 \mathrm{ml}$ fractions being collected. An aglycone (1a) $(0.9 \mathrm{mg}, 26 \%)$ was recovered in fractions 23 - 27. Aglycone (4a): Colorless syrup, $[\alpha]_{\mathrm{D}}^{25}-21.0(c$ $=0.06, \mathrm{MeOH}) ;{ }^{1} \mathrm{H}-\mathrm{NMR}\left(\mathrm{CD}_{3} \mathrm{OD}, 400 \mathrm{MHz}\right)$ : Table 2; ${ }^{13} \mathrm{C}-\mathrm{NMR}\left(\mathrm{CD}_{3} \mathrm{OD}, 100 \mathrm{MHz}\right.$ ): Table 2; HR-ESI-MS (positive-ion mode) $\mathrm{m} / z: 461.1786[\mathrm{M}+\mathrm{Na}]^{+}$(Calcd for $\mathrm{C}_{22} \mathrm{H}_{30} \mathrm{O}_{9} \mathrm{Na}, 461.1788$ )

\subsection{Sugar Analysis}

About $350 \mu \mathrm{g}$ each of 1 and 2 was hydrolyzed with $1 \mathrm{~N}$ $\mathrm{HCl}(0.2 \mathrm{ml})$ at $90^{\circ} \mathrm{C}$ for $2 \mathrm{~h}$. The reaction mixtures were washed with an equal amount of EtOAc and then passed through Amberlite MB-3. The pass-through fractions were evaporated to dryness to give residues. The residues were dissolved in $0.1 \mathrm{ml}$ of dry pyridine and then $0.5 \mathrm{mg}$ of L-cysteine methyl ester was added. To these mixtures, $1.4 \mathrm{mg}$ of $o$-tolylthioisocyanate in $70 \mu \mathrm{l}$ of pyridine was added, followed by standing at $60^{\circ} \mathrm{C}$ for $1 \mathrm{~h}$. The reaction 
mixtures were analyzed by HPLC [ODS: Cosmosil 5C18ARII $(4.6 \mathrm{~mm} \times 250 \mathrm{~mm}), \mathrm{CH}_{3} \mathrm{CN}-50 \mathrm{mM} \mathrm{H} \mathrm{H}_{3} \mathrm{PO}_{4}$ (1:3), $0.8 \mathrm{ml} / \mathrm{min}$, UV detector at $250 \mathrm{~nm}$ ] to give peaks for thiocarbamoylthiazolidine derivatives of $\mathrm{D}$-glucose and D-apiose at $18.0 \mathrm{~min}$ and $31.0 \mathrm{~min}$, respectively [21]. The peaks were identified by co-chromatography with thiocarbamoyl-thiazolidine derivatives of authentic Dglucose and D-apiose.

About $500 \mu \mathrm{g}$ of each compound, except for 1 and 2, was hydrolyzed with $1 \mathrm{~N} \mathrm{HCl}(0.1 \mathrm{ml})$ at $90^{\circ} \mathrm{C}$ for $2 \mathrm{~h}$. The reaction mixtures were partitioned with an equal amount of EtOAc $(0.1 \mathrm{ml})$, and the water layers were analyzed with a chiral detector (JASCO OR-2090plus) on an amino column [Asahipak $\mathrm{NH}_{2} \mathrm{P}-504 \mathrm{E}, \mathrm{CH}_{3} \mathrm{CN}$ $\mathrm{H}_{2} \mathrm{O}(3: 1), 1 \mathrm{ml} / \mathrm{min}$ ]. A hydrolyzate of 4 gave a peak for D-glucose at $7.9 \mathrm{~min}$, and ones of 3,5 and 6 gave peaks for L-arabinose and D-glucose at $6.1 \mathrm{~min}$ and $13.7 \mathrm{~min}$, respectively, with positive optical rotation signs. The peaks were identified by co-chromatography with authentic samples.

\section{Acknowledgements}

The authors are grateful for access to the superconducting NMR instrument (JEOL JNM $\alpha-400$ ) at the Analytical Center of Molecular Medicine of the Hiroshima University Faculty of Medicine and an Applied Biosystem QSTAR XL system ESI (Nano Spray)-MS at the Analysis Center of Life Science of the Graduate School of Biomedical Sciences, Hiroshima University. The authors are also grateful for the use of the NMR instrument (JEOL ECA-600) at the Natural Science Center for Basic Research and Development, Hiroshima University. This work was supported in part by Grants-in-Aid from the Ministry of Education, Culture, Sports, Science and Technology of Japan (Nos. Nos. 22590006 and 23590130), the Japan Society for the Promotion of Science, and the Ministry of Health, Labour and Welfare. Thanks are also due to the Research Foundation for Pharmaceutical Sciences and the Takeda Science Foundation for the financial support.

\section{REFERENCES}

[1] S. Hatusima, "Flora of the Ryukyus. Added and Corrected," The Biological Society of Okinawa, Naha, 1975, p. 476.

[2] C. Sunil and S. Ignacimuthu, "In vivo and in vitro Antioxidant Activity of Symplocos cochinchinensis S. Moore Leaves Containing Phenolic Compounds," Food and Chemical Toxicology, Vol. 49, No. 7, 2011, pp. 16041609. doi:10.1016/j.fct.2011.04.010

[3] C. Sunil, S. Ignacimuthu and P. Agastian, "Antidiabetic Effect of Symplocos cochinchinensis (Lour.) S. Moore in
Type 2 Diabetic Rats," Journal of Ethnopharmacology, Vol. 134, No. 2, 2011, pp. 298-304. doi:10.1016/i.jep.2010.12.018

[4] M. R. Khan, M. Kihara and A. D. Ornoloso, "Antimicrobial Activity of Symplocos cochinensis," Fitoterapia, Vol. 72, No. 7, 2001, pp. 825-828. doi:10.1016/S0367-326X(01)00314-8

[5] H. Otsuka, Ya. Takeda, K. Yamasaki and Yo. Takeda, "Structural Eelucidation of Dendranthemosides A and B: Two New $\beta$-Ionone Glucoside from Dendranthema shiwogiku," Planta Medica, Vol. 58, No. 4, 1992, pp. 373375. doi:10.1055/s-2006-961489

[6] A. G. González, J. A. Guillermo, A. G. Ravelo, I. A. Jimenez and M. P. Gupta, "4,5-Dihydroblumenol A, a New Nor-Isoprenoid from Perrottetia multiflora," Journal of Natural Products, Vol. 57, No. 3, 1994, pp. 400-402. doi:10.1021/np50105a013

[7] H. Otsuka, K. Kamada, C. Ogimi, E. Hirata, A. Takushi and Y. Takeda, "Alangionosides A and B, Ionol Glycosides from Leaves of Alangium premnifolium," Phytochemistry, Vol. 35, No. 5, 1994, pp. 1331-1334. doi:10.1016/S0031-9422(00)94848-9

[8] A. Inada, Y. Nakamura, M. Konishi, H. Murata, F. Kitamura, H. Toya and T. Nakanishi, "A New Ionone Glucoside and a New Phenylpropanoid Rhamnoside from Stems of Ampelopsis brevipedunculata (Maxim.) Trautv.," Chemical and Pharmaceutical Bulletin, Vol. 39, No. 9, 1991, pp. 2437-2439.

[9] K. Umehara, I. Hattori, T. Miyase, A .Ueno, S. Hara and C. Kageyama, "Studies on the Constituents of Leaves of Citrus unshiu Marcov.," Chemical and Pharmaceutical Bulletin, Vol. 36, No. 12, 1988, pp. 5004-5008.

[10] T. Seto, T. Tanaka, O. Tanaka and N. Naruhashi, " $\beta$-Gluco-syl Esters of $19 \alpha$-Hydroxyursolic Acid Derivatives in Leaves of Rubus Species," Phytochemistry, Vol. 23, No. 12, 1984, pp. 2829-2834. doi:10.1016/0031-9422(84)83023-X

[11] T. Morikawa, L. -B. Wang, K. Ninomiya, S. Nakamura, H. Matsuda, O. Muraoka, L. -J. Wu and M. Yoshikawa, "Medicinal Flowers. XXX. Eight New Glycosides, Everlastosides F-M, from the Flowers of Helichrysum arenarium," Chemical and Pharmaceutical Bulletin, Vol. 57, No. 8, 2009, pp. 853-859. doi:10.1248/cpb.57.853

[12] R. Kasai, M. Suzuno, J. Asakawa and O. Tanaka, "Carbon-13 Chemical Shifts of Isoprenoid- $\beta$-D-glucopyrano-sides and $-\beta$-D-mannopyranosides. Stereochemical Influences of Aglycone Alcohols," Tetrahedron Letter, Vol. 18, No. 2, 1977, pp. 175-178. doi:10.1016/S0040-4039(01)92581-X

[13] I. Ohtani, T. Kusumi, Y. Kashman and H. Kakisawa, "High-Field FT NMR Application of Mosher's Method. The Absolute Configurations of Marine Terpenoids," Journal of American Chemical Society, Vol. 113, No. 11, 1991, pp. 4092-4096. doi:10.1021/ja00011a006

[14] K. Matsunami, H. Otsuka and Y. Takeda, "Structural Revisions of Blumenol C Glucoside and Byzantionoside 
B," Chemical and Pharmaceutical Bulletin, Vol. 58, No. 3, 2010, pp. 438-441. doi:10.1248/cpb.58.438

[15] A. C. H. Braga, S. Zacchino, H. Badano, M. G. Sierra and E. A. Rúveda, " ${ }^{13} \mathrm{C}$ NMR Spectral and Conformational Analysis of 8-O-4' Neolignans," Phytochemistry, Vol. 23, No. 9, 1984, pp. 2025-2028.

[16] C. Huo, H. Liang, Y. Zhao, B. Wang and Q. Zhang, "Neo-Lignan Glycosides from Symplocos caudata," Phytochemistry, Vol. 69, No. 3, 2008, pp. 788-795. doi:10.1016/j.phytochem.2007.08.022

[17] A. Arnoldi and L. Merlini, "Asymmetric Synthesis of 3Methyl-2-phenyl-1,4-Benzodioxanes. Absolute Configuration of the Neolignans Eusiderin and Eusiderin $\mathrm{C}$ and D," Journal of Chemical Society Perkin Transaction I, No. 6, 1985, pp. 2555-2557. doi:10.1039/p19850002555

[18] K. Kónya, T. Kurtán, A. Kiss-Szikszai, L. Juhász and S. Antus, "A General CD-Method for the Configurational
Assignment of Erythro-8,4'-Oxyneolign-8'-Enes," Arkivoc, Vol. 8, 2004, pp. 72-78.

[19] C. Sunil, S. Ignacimuthu and P. Agastian, "Antidiabetic Effect of Symplocos cochinchinensis (Lour.) S. Moore. in Type 2 Diabetic Rats," Journal of Ethnopharmacology, Vol. 134, No. 2, 2011, pp. 298-304. doi:10.1016/j.jep.2010.12.018

[20] T. Ishii and M. Yanagisawa, "Synthesis, Separation and NMR Spectral Analysis of Methyl Apiofuranosides," Carbohydrate Research, Vol. 313, No. 3-4, 1998, pp. 189-192. doi:10.1016/S0008-6215(98)00262-6

[21] T. Tanaka, T. Nakashima, T. Ueda, K. Tomii and I. Kouno, "Facile Discrimination of Aldose Enantiomers by Reversed-Phase HPLC," Chemical and Pharmaceutical Bulletin, Vol. 55, No. 6, 2007, pp. 899-901. doi:10.1248/cpb.55.899 